\title{
Beating the tissue shortage
}

\section{Washington}

AN UGLY dispute over the handling of human brains from the Philadelphia coroner's office is spotlighting a nationwide shortage of brain tissue for medical research.

Philadelphians reacted with outrage last week when media reports revealed that the Philadelphia Medical Examiner had removed the brains from about 25 cadavers and sent them to the University of Pennsylvania Medical School, where most were used for classroom instruction. The problem was that the transfers had been undertaken without the knowledge or permission of the families of the deceased.

Officials defend the transaction as completely legal and of "mutual benefit". The medical school got fresh brains from the cadavers of people who had been previously healthy, and the coroner got free dissection reports on possible victims of foul play by the medical school pathologists who examined the brains with their students.

The families of the deceased were not persuaded by these arguments, however, and the coroner's office has temporarily stopped the brain trade while it considers its options.

The medical school's arrangement with the Medical Examiner offered a way to deal with a problem that bedevils schools across the country: a lack of human organs and tissue needed for research and for teaching. In particular, by helping the coroner's office, the medical school got to examine the brains SCIENTIFIC MISCONDUCT of generally young, healthy people - an unparalleled opportunity to spot early signs of neurological disease, as well to as collect postmortem epidemiological data on a cross-section of the population, not just the sick and elderly.

Collaboration between coroners and medical schools is common, says Philadelphia deputy medical examiner Ian Hood. In small cities, the medical examiner's office is often located in the local medical school hospital, and students are routinely invited to participate in autopsies. Hood believes that the only distinction in the Philadelphia case is that the entire brains were taken out of the building to be examined elsewhere, even if it was just a block away.

Observers of the brain deal disagree as to whether it is legal under state and local laws, and the ethics of it are just as problematic. Across the state from Philadelphia, former Pittsburgh coroner Cyril Wecht has his qualms.

"Technically, it really is professionally unethical," says Wecht, who is a University of Pittsburgh pathologist, a lawyer and a past president of the American Academy of Forensic Sciences. "I realize that gathering the appropriate permissions would be a procedural mess, but I believe that a substantial percentage of the families would be disturbed to discover that the brains [of their relatives] had not been buried with the rest of the body." If lawsuits force the brain deals to stop, Hood says, promising research could suffer. "One of the saddest aspects of this whole thing is that we may have to curtail our research programmes", he says. The Penn researchers were looking for undetected lesions in the brains that might provide scarce data on the early, asymptomatic, progression of Alzheimer's and Huntington's disease. Hood's office was also collaborating with researchers at the Philadelphia Children's Hospital to study the bodies of apparent victims of sudden infant death syndrome, looking for the clues of inborn errors of metabolism.

Christopher Anderson ENDANGERED SPECIES

\section{Killer cows prompt shell suit}

\section{Washington}

ONE day last month, on a barren stretch of Arizona desert near the Utah border, a cow squashed a tortoise. The cow's forefoot sank 14 inches through loose sand, finally stopping in the underground burrow of a desert tortoise, who was home. After crushing the animal's shell, the cow pulled its foot out of the hole and walked on.

That would have been that if this were an ordinary tortoise. But it was not, and now the US government is about to be sued to prevent further such attacks by cows.

As one of fewer than 175 of the endangered desert tortoises in the Arizona-Utah desert, the doomed animal was wearing a radio transmitter so that it could be monitored by government researchers trying to

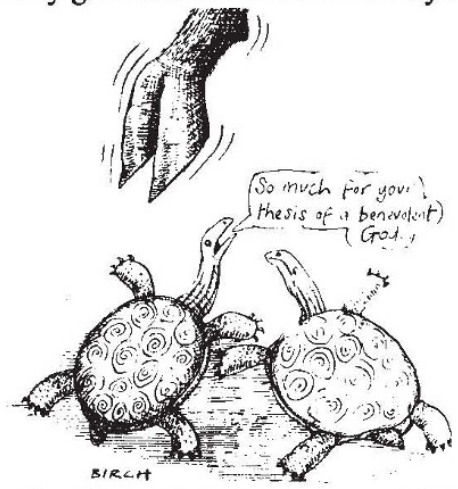

save the 10- to 15 -inch species, which can live to be more than 100 years old. Within hours of the accident the scientists were on the scene, in time to photograph the cow tracks and euthanize the tortoise, which was still alive.

Last week, four environmental groups filed an intent to sue the US Department of the Interior and its Bureau of Land Management for allowing cattle to graze in the desert tortoise habitat. The Natural Resource Defense Council, Defenders of Wildlife, the Environmental Defense Fund and the Humane Society claim that the injuries suffered by the tortoise correspond closely to shell damage in other killings that had previously been attributed to coyotes.

ChristopherAnderson approved by the Administration. The reason, he says, is that the proposed regulations are not a "rule-making" but rather a "policy- 